\title{
Iwona Bak
}

dr hab.

Zachodniopomorski Uniwersytet Technologiczny w Szczecinie, Wydział Ekonomiczny, Katedra Zastosowań Matematyki w Ekonomii, Zakład Statystyki

iwona.bak@zut.edu.pl

\section{Beata Szczecińska}

dr inż.

Zachodniopomorski Uniwersytet Technologiczny w Szczecinie, Wydział Ekonomiczny, Katedra Analizy Systemowej i Finansów

beata.szczecinska@zut.edu.pl

DOI: 10.35117/A_ENG_16_01_03

\section{Statistical analysis of road safety in Poland with application of taxonomic methods}

\begin{abstract}
The road safety is an area of public security, which is a basic need of every human being. One of the sources of the threats are road traffic offenses related in violation of safety rules. The aim of the article is to analyze road safety throughout the country and in individual provinces. In the study were used spatial and time data included in e.g. in the Regional Bank Data in the years 2001-2014 and the Police research papers available on the Internet. The statistical analysis and application of the Hellwig's taxonomic measure of development allowed the characterization of road traffic offenses in Poland and to identification of regions with the highest level of road safety. It turned out, that despite the presence of a number of negative factors increasing the risk of accidents, the security situation on Polish roads improves. The number of accidents and their victims decreases. Particularly positive changes on Polish roads were noted after the Polish accession to the European Union.
\end{abstract}

Keywords: Road traffic offences; Road safety; Taxonomic measure of development

\section{Introduction}

In everyday meaning the offense is an action leading to the fracture of a legal norm. From art. 1 of the Act Penal Code of 6 June 1997 [3] the crime is a criminal offense under the law in force at the time of its commission. The structure of offenses committed in Poland is relatively stable. [6] The largest group of recorded crimes are criminal offences $(68 \%)$, followed by road traffic (15\%) and economic (13\%).

Road traffic offence is a breach, even unintentionally, the safety in land traffic, if the effect of the infringement was [12]:

- bringing a disaster on land traffic,

- bringing an immediate risk of such a disaster,

- death, bodily injury or health disorder of another person or serious damage to property that does not belong the offender.

Road traffic offenses are still not perceived in Poland as an important enough problem. Meanwhile, in 2004-2013, they absorbed the lives of over 47,000 people, with a further 554,000 people were injured. The economic costs of road accidents in Poland is over 28 billion zł per year. Although you can see the improvement in this area during the last decade, Poland, compared to other European Union countries, it remains a country with a low level of road safety. Location of our country on the map of Europe, its location on the transport route east-west, generates a very large transit traffic. According to data from the General 
Headquarters of the Border Guard, in 2014 the external borders of the EU to Polish drove 14 214660 vehicles, including 12184216 cars [14].

Road safety is an area of public safety, which is a basic need of every human being, and his unsatisfied does not allow the implementation of other needs and hinders the development of the individual. This is confirmed by, among other things commonly known theory of Maslow's hierarchy of needs A. [5], according to which the security is second in the hierarchy of human need (just after physiological needs such as hunger, thirst). One of the sources of of its threats are traffic offenses related to the violation of safety rules. Due to the high social and economic costs of road accidents are increasingly carried out the analysis of statistics and economics of these crimes, because effects of breaking the law are long-term and felt at the macro and micro [13].

This article aims to analyze the road safety throughout the country and in different provinces. The study used data space-time from the years 2001-2014 included, among others, in the Regional Data Bank [1] and available online studies Police. Statistical analysis and application of Hellwig's taxonomic measure of development allowed the characterization of traffic offenses in Poland and to identify regions characterized by the highest level of road safety.

\section{Characteristics of road traffic offenses in Poland}

For several years in Poland is clearly visible downward trend in the number of road traffic offenses detected. In 2014, they recorded 86,747, which means a decrease in the number of crimes by $38.4 \%$ compared to the previous year. From 2001 to 2006, the number of such crimes increased steadily (fig. 1). In the next years there has been noted a decreasing tendency. In 2014, the number of road traffic offenses was lower than recorded in 2001 by almost $40 \%$.

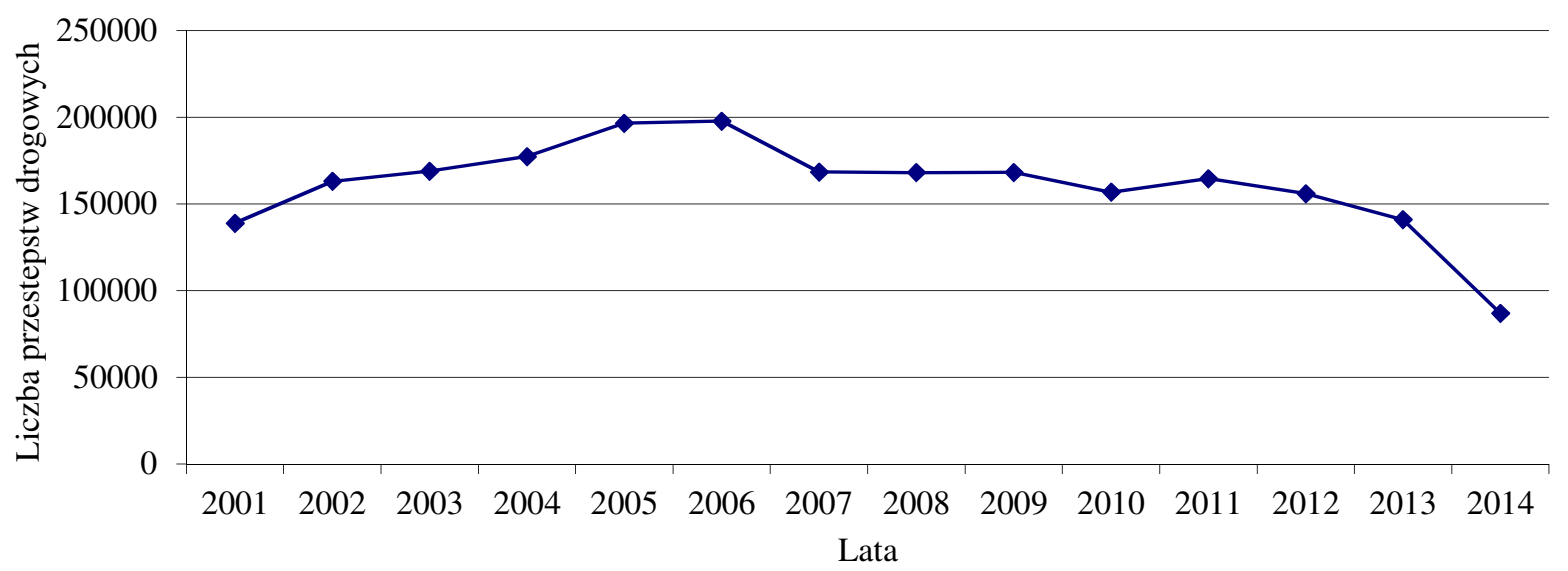

1. The number of traffic offenses detected in Poland in years 2001-2014

Except the size of crime itself in the sense of residents safety, greatly affects the percentage of offenses detected. The low detection rate increases insecurity and impunity among criminals, which may lead to the escalation of crime and the emergence of feelings of fear in the remaining citizens. In case of road traffic offenses the situation looks optimistic. In the analyzed period, the detection of this type of crime was very high and ranged from 98.9 to $99,4 \%$.

The most common committed traffic crime is driving a motor vehicle or other vehicle on land traffic in a state of intoxication. Another particularly important from a social point of view crime is causing a road traffic accident [6].

In 2014 Poland reported nearly 35 thousand road accidents. $82.1 \%$ of accidents arose through the fault of drivers [14]. Figure 2 shows the structure. More than half of the cases 
were associated with non-compliance by drivers with right of way $(26.8 \%)$ and inadequacy of speed to traffic conditions $(26.1 \%)$. A large share of the cases concerned the addition of failure to a safe distance between vehicles $(8.1 \%)$, and not resigning a primacy to a pedestrian $(7,8 \%)$.

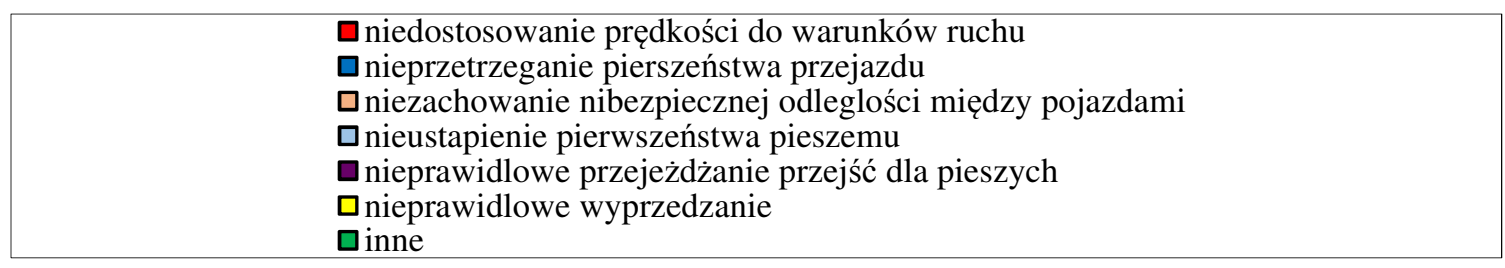
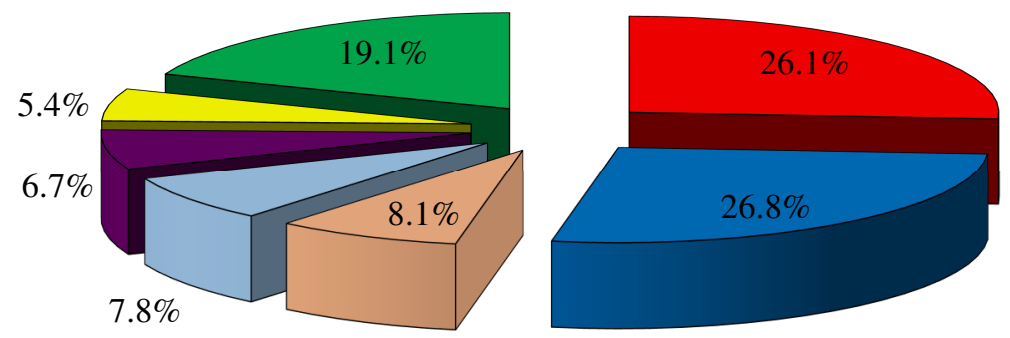

2. The structure of road accidents due to the fault of drivers in Poland in 2014

In table 1, taking into account the number of people given the number of crimes and road accidents in Poland and provinces in three years: 2005, 2010 and 2013. It turns out that the region is characterized by a very large diversity in this regard. In 2013 in the lódzkie voivodeship reported 152.4 accidents per 100 thousand of the population, while in the kujawsko-pomorskie rate was 56.5 , so $63 \%$ less.

Tab. 1. The number of crimes and road accidents, taking into account the number of inhabitants in the Polish provinces in years: 2005, 2010 and 2013

\begin{tabular}{|c|c|c|c|c|c|c|}
\hline \multirow[t]{2}{*}{ Województwa } & \multicolumn{3}{|c|}{$\begin{array}{l}\text { przestępstwa drogowe na tys. } \\
\text { ludności }\end{array}$} & \multicolumn{3}{|c|}{$\begin{array}{l}\text { wypadki drogowe na } 100 \text { tys } \\
\text { ludności }\end{array}$} \\
\hline & 2005 & 2010 & 2013 & 2005 & 2010 & 2013 \\
\hline POLSKA & 5,15 & 4,07 & 3,66 & 126,1 & 100,8 & 93,1 \\
\hline Dolnośląskie & 4,89 & 4,49 & 3,92 & 109,0 & 78,6 & 88,9 \\
\hline Kujawsko-pomorskie & 6,01 & 3,76 & 3,71 & 104,3 & 71,0 & 56,5 \\
\hline Lubelskie & 3,13 & 2,82 & 2,75 & 112,2 & 83,5 & 69,4 \\
\hline Lubuskie & 4,14 & 3,16 & 2,72 & 85,2 & 82,6 & 73,1 \\
\hline Łódzkie & 6,37 & 4,67 & 4,31 & 184,4 & 163,5 & 152,4 \\
\hline Małopolskie & 4,87 & 3,71 & 3,65 & 135,8 & 120,0 & 112,0 \\
\hline Mazowieckie & 6,36 & 4,28 & 4,31 & 125,1 & 98,5 & 86,1 \\
\hline Opolskie & 5,34 & 4,82 & 3,78 & 96,7 & 82,2 & 78,8 \\
\hline Podkarpackie & 7,19 & 6,42 & 5,22 & 106,9 & 92,2 & 84,9 \\
\hline Podlaskie & 4,96 & 4,01 & 4,33 & 98,8 & 70,4 & 61,8 \\
\hline Pomorskie & 4,35 & 5,76 & 4,24 & 139,3 & 116,9 & 115,0 \\
\hline Śląskie & 6,43 & 4,83 & 3,82 & 135,6 & 108,2 & 98,5 \\
\hline Świętokrzyskie & 6,27 & 4,98 & 4,88 & 148,3 & 122,7 & 110,3 \\
\hline Warmińsko-mazurskie & 3,89 & 3,96 & 3,63 & 135,5 & 118,7 & 112,0 \\
\hline Wielkopolskie & 4,98 & 3,69 & 2,79 & 126,6 & 85,0 & 75,9 \\
\hline Zachodniopomorskie & 6,42 & 4,05 & 3,42 & 110,7 & 86,1 & 87,4 \\
\hline Współczynnik zmienności & 20,53 & 20,42 & 18,00 & 19,35 & 24,25 & 25,85 \\
\hline
\end{tabular}


A similar situation related to road traffic offenses per thousands of the population most of them took place in podkarpackie voivodeship (5.22), while the least in lubuskie (2.72). Positive noteworthy deserve decline in both these indicators in the analyzed period This applies to the entire country, as well as individual provinces Only in the mazowieckie and podlaskie it found a slight increase in the number of road traffic offenses in 2013 compared to 2010. In case of of traffic accidents similar situation concerned the provinces of dolnośląskie and zachodniopomorskie.

Recent years have brought a significant improvement in road safety in Poland. Since 2008, the number killed in road accidents fell by an average of 9\% yearly Similar tendency related to the number of people seriously injured, though here the decline was slightly lower and amounted to 6\% [11] Despite these positive trends, Poland still occupies unfavorable position in the ranking of the security of states of the European Union In 2012, with the index more than 9 people killed per 100 thousand locals, we were the third country with the highest level of threat to life on the road, just after Lithuania and Romania. Every 8 fatal road traffic victim was a resident of Poland. In 2013, the situation has not improved significantly, as evidenced by the following indicators: the number of accidents per 100 thousand residents 93, the number of dead at 100 thousands of residents - 9, the severity of accidents (number of people killed in 100 accidents) - 9, the density of accidents (number of accidents per $100 \mathrm{~km}$ of roads) - 12. in the ranking of safety on European roads developed by the European Commission in March 2015 Poland moved up 3 positions compared to previous years. Compared to 2013, the height of the demographic ratio specified number of kill / 100 thousands of residents has improved and now stands at 8.3 These data, however, still situate our country in the group of countries characterized by higher than average for the EU threat level, which according to preliminary data, the European Commission reached in 2014 a value of 5.1 kill / 100 thousands of residents [10].

In ten Polish voivodeships the severity of accidents rate was higher than the national (fig. 3) Most killed in 100 accidents reported in voivodeships: podlaskie (18), lubelskie (17) and kujawsko-pomorskie (15), the least in małopolskie and śląskie (after 6) nd the ratio of the density of accidents in most provinces was below the national average The lowest number of accidents per $100 \mathrm{~km}$ was characterized by pdlaskie (6) In three provinces (pomorskie, śląskie and łódzkie), the rate was more than three times higher.

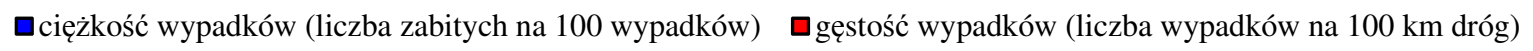

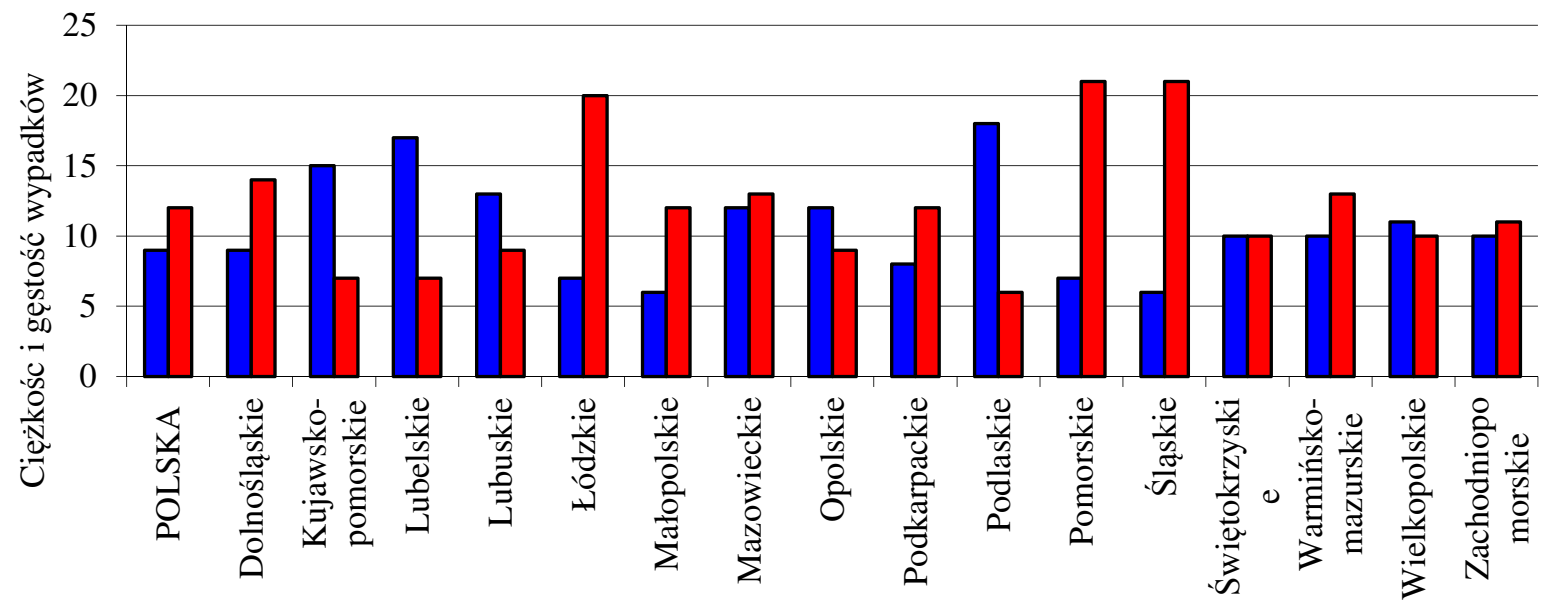

3. Indicators of gravity and density of accidents in Poland and according to provinces in 2013 


\section{Spatial typology of road traffic offenses}

The presence of significant differences in the spatial distributions of road traffic offenses tends to develop a typology of spatial aimed at synthetic illustrate the phenomenon. In case of the community, where the units are described by a large set of features is most commonly used methods of multidimensional comparative analysis, and in particular the methods of taxonomic [2] Taxonomic measures of development are synthetic variables that replace the object description of the study using a set of diagnostic features described by one aggregate size [7]. For this purpose are used pattern and non-pattern measures [4; 9]. In non-pattern methods synthetic variable is a function of the normalized values of the input variables However, in the pattern methods used reference is the concept of the reference object, or a model of the desired object, the best values of input variables. Synthetic measure is constructed by measuring the distance between the observed object and the object of the reference [8] The study for the construction of taxonomic measure of development used the reference pattern method in the classical approach, i.e. the Z. Hellwig taxonomic measure of development based on standardized values $z_{i j}$ diagnostic features [7]:

$z_{i j}=\frac{x_{i j}-\bar{x}_{j}}{S_{j}},(\mathrm{i}=1,2, \ldots, \mathrm{n}, \mathrm{j}=1,2, \ldots, \mathrm{m})$,

where:

$\bar{x}_{j}-$ the arithmetic average of diagnostic features,

$S_{j}$ - the standard deviation of diagnostic feature.

For each object, the study determined distance from the established pattern of development with the form:

$d_{i}=\sum_{j=1}^{m}\left|z_{i j}-\varphi_{j}\right|,(\mathrm{i}=1,2, \ldots, \mathrm{n})$,

wherein for stimulants $\varphi_{j}=\max _{i=1,2, \ldots, n} z_{i j}$, and for destimulants $\varphi_{j}=\min _{i=1,2, \ldots, n} z_{i j}$.

Synthetic measure of development determined by the formula:

$z_{i}=1-\frac{d_{i}}{d_{-}}$

where : $d_{-}=\bar{d}+2 S_{d}$ ( $\bar{d}$-the arithmetic average of the coordinate distance vector $\mathbf{d}$, and $S_{d}-$ their standard deviation).

Based on average and standard deviation of taxonomic measure of development, a set of all regions in Poland divided into four groups, including objects with the values of the following ranges:

- group 1 of voivodeships: $z_{i} \geq \bar{z}+S_{z}$ - low road crime rate,

- group 2 of voivodeships: $\bar{z}+S_{z}>z_{i} \geq \bar{z}$ - the average level of road crime,

- group 3 of voivodeships: $\bar{z}>z_{i} \geq \bar{z}-S_{z}$ - high level of road crime,

- group 4 of voivodeships: $z_{i}<\bar{z}-S_{z}$ - very high level of road crime.

In the typological proceedings were taken into account characteristics for traffic offenses. They were converted into indicators of intensity - in the denominators each placing different sizes of determining which are related to the specificity of the studied phenomenon. The obtained intensity ratios were subjected to verification of substantive and formal statistical. Finally, the greatest value for typological aims have the following diagnostic features:

- the number of traffic offenses per 100 thousand population,

- the number of road accidents per 100 thousand population,

- the number of fatalities per 100 thousand population, 
- indicator of the severity of accidents,

- density rate of accidents.

All assumed for the survey diagnostic features were treated as destimulants, qualities that higher values correspond to higher levels of crime road. Results of this study are shown in table 2. It turns out that in 2013 the safest on the road was in three provinces: wielkopolska, dolnośląskie and małopolska (I typological group). This group is characterized by the lowest number of traffic offenses committed and the lowest number of road fatalities per 100 thousand population. By far the worst situation in terms of the examined phenomenon took place in the łódzkie voivodship, where per 100 thousand inhabitants committed many crimes and accidents with a large number of fatalities.

Tab. 2. Sorting of Polish provinces because of the level of crime on the basis of the road taxonomic meter development $\left(z_{\mathrm{i}}\right)$

\begin{tabular}{|c|c|c|c|}
\hline Lp. & Województwa & Miernik rozwoju & Grupa typologiczna \\
\hline 1 & Wielkopolskie & 0,5932 & I \\
\hline 2 & Małopolskie & 0,4933 & I \\
\hline 3 & Dolnośląskie & 0,4837 & I \\
\hline 4 & Opolskie & 0,4642 & II \\
\hline 5 & Kujawsko-pomorskie & 0,4416 & II \\
\hline 6 & Lubuskie & 0,4350 & II \\
\hline 7 & Zachodniopomorskie & 0,3733 & II \\
\hline 8 & Lubelskie & 0,3663 & III \\
\hline 9 & Warmińsko-mazurskie & 0,3335 & III \\
\hline 10 & Śląskie & 0,3271 & III \\
\hline 11 & Mazowieckie & 0,2972 & III \\
\hline 12 & Świętokrzyskie & 0,2913 & III \\
\hline 13 & Podlaskie & 0,2673 & III \\
\hline 14 & Pomorskie & 0,2552 & III \\
\hline 15 & Podkarpackie & 0,2462 & IV \\
\hline 16 & Łódzkie & 0,0843 & \\
\hline
\end{tabular}

The spatial arrangement of traffic crime, was also examined at the lowest regional level available in the statistics of the Central Statistical Office, which is based on the subregions (NTS-3 level, in the nomenclature of international statistics). In 2013, most traffic offenses were found in the city of Łódź, the least in Poznań. Most fatalities per 100 thousand vehicles were recorded in the district of Krosno (podkarpackie province), and the least in the district ciechanowsko-płockie (mazowieckie voivodship).

\section{Conclusions}

Aspects of road safety consist a series of complex issues, ranging from road infrastructure, traffic management, and control issues compliance with regulations by drivers, prevention and education. Despite the prevalence of a number of negative factors increasing the risk of a crash, the state of safety on polish roads improves. It decreases both the number of accidents and their victims. Over the last 14 years, the number of fatalities fell from 5.5 thousand people in 2001 to 3.2 thousand in 2014 (down 42.1\%) and the number of people injured more than 68 thousand to 42 thousand (down 37.6\%) Importantly, downward tendency remains virtually throughout the period considered, despite the steady increase in the number of vehicles on polish roads. It is the culmination of a series of actions taken by the state organs, academic institutions, non-governmental organizations, media representatives, as well as individuals. 
Efforts are new challenges, especially in the field of further dissemination of the culture of driving and compliance with traffic laws This applies mainly speeding, driving under the influence of alcohol and ensure the safety of unprotected road users. A lot has changed on polish roads after the Polish accession to the European Union This applies particularly intense expansion and modernization of infrastructure. Improved supervision of traffic, improved rescue system and taken a number of initiatives on education and prevention.

Used in the article Hellwig's taxonomic measure of development allowed to organize polish provinces because of the level of crime road. In addition, the value of this instrument enabled the separation of the four typological groups of of voivodeships characterized by a similar situation in terms of the studied phenomenon. It turned out that in 2013 the most secure provinces were: wielkopolskie, małopolskie and dolnośląskie, which were characterized by the lowest number of traffic offenses committed. In the group with the highest level of crime road there were only łódzkie province.

\section{Source materials}

[1] Bank Danych Regionalnych, www.stat.gov.pl, 12.10.2015.

[2] Bąk I., Szczecińska B. Analiza atrakcyjności turystycznej miast wojewódzkich w Polsce, GUS, Warszawa, Wiadomości Statystyczne, 2014 nr 12, s. 80-95.

[3] Dz.U.1997, Nr 88, poz. 553 z późn. zm.

[4] Grabiński T. Metody taksonometrii, Akademia Ekonomiczna w Krakowie, Kraków, 1992.

[5] Maslow A.H. Teoria hierarchii potrzeb W: Reykowski J. (red.) Problemy osobowości i motywacji w psychologii amerykańskiej, PWN, Warszawa, 1964.

[6] Mordwa S. Struktura i typologia przestrzenna przestępczości w Polsce - przykład wykorzystania walidacji liczby skupień w metodzie k-średnich, Wydawnictwo Uniwersytetu Łódzkiego, Acta Universitatis Lodziensis, Folia Geographica SocioOeconomica, 2012 nr 12, s. 94, 100-101.

[7] Nowak E. Metody taksonomiczne w klasyfikacji obiektów społeczno-gospodarczych, PWE, Warszawa, 1990, s. 88, 89.

[8] Panek T. Statystyczne metody wielowymiarowej analizy porównawczej, Oficyna Wydawnicza SGH, Warszawa, 2009, s. 58.

[9] Pociecha J., Podolec B., Sokołowski A., Zając K. Metody taksonomiczne w badaniach społeczno-ekonomicznych, PWN, Warszawa, 1988, s. 71.

[10] Podsumowanie stanu BRD w 2014 r. oraz nowe wyzwania w programie realizacyjnym 2015-2016, Krajowa Rada Bezpieczeństwa Ruchu Drogowego, www.krbrd.gov.pl, 08.10.2015.

[11]Raport o stanie bezpieczeństwa w Polsce 2013, Ministerstwo Spraw Wewnętrznych, 2013.

[12] Uchwała Pełnego Składu Izby Karnej Sądu Najwyższego z dnia 28 lutego 1975 roku, V KZP 2/74, OSNKW 1975/3-4 poz. 33.

[13] Wierzbicka A., Żółtaszek A. Analiza bezpieczeństwa publicznego w krajach europejskich, GUS, Warszawa, Wiadomości Statystyczne, 2015 nr 8, s. 66.

[14] Wypadki drogowe w Polsce w 2014 roku, Komenda Główna Policji, Biuro Prewencji i Ruchu Drogowego, Wydział Ruchu Drogowego, Warszawa, 2015, s. 5, 25-26, file:///C:/Users/Wlasciciel/Downloads/raport_roczny_ruch_drogowy_2014_r_.pdf, 09.10.2015. 